As-Syifaa Jurnal Farmasi Desember 2020;12(2):76-83.

ISSN : 2502-9444 (electronic); 2085-4714 (printed)

Journal Homepage : http://jurnal.farmasi.umi.ac.id/index.php/as-syifaa

\title{
KARAKTERISASI EKSTRAK TERPURIFIKASI KELOPAK ROSELLA (Hibiscsus sabdariffa L.) DAN AKTIVITASNYA SEBAGAI ANTIHIPERTENSI PADA TIKUS SPRAGUE DAWLEY
}

\author{
Fita Sari, Dyah Aryantini \\ Institut IImu Kesehatan Bhakti Wiyata, Kediri, Jawa Timur, Indonesia \\ Email: fita.sari@iik.ac.id
}

\begin{abstract}
The characterization was ensuring quality of traditional raw materials for drug preparations. Purification extract was a part of extract which released from compounds it was more effective for pharmacological activities. The effectivity an antihypertensive was still very rarely proven by use of traditional ingredients, especially from purified rosella. The aim of the study is characterization and knowing of calyx purified extract of rosella which is suspected to have antihypertensive activity in vivo. The method was done by purifying, characterization, determined of quercetin, and antihypertensive activity. Positive control (captopril), negative (CMC Na 0,5\%), test of 12,5 dan $25 \mathrm{mg} / \mathrm{kg}$ BB. Descriptive data analysis for characterization, linear regression analysis of quercetin and antihypertensive statistical testing. The results for characterization of $1.41 \%$ water content, specific gravity $0.63 \% \mathrm{w} / \mathrm{v}$, drying losses $2.82 \%$ and $2.31 \%$. Levels of quersetin of $7.02 \pm 0.15$. The activity as antihypertensive result decrease in blood pressure which is indicated by a significant difference between the positive control and the test group. The $25 \mathrm{mg} / \mathrm{kg}$ body weight ETKR dose is an effective dose in reducing blood pressure. The non-specific character of purified extract of rosella calyx, FHI and through oral administration of ETKR can reduce the blood pressure of test animals with an effective dose of 25mg / $\mathrm{kgBB}$. This research still requires identification of bioactive compounds responsible for these activities.
\end{abstract}

Key Words: Antihypertension, characterization, extract, purification, rosella.

\section{PENDAHULUAN}

Keadaan tidak normal pada tubuh merupakan gejala sakit yang disebabkan oleh banyak faktor. Terdapat banyak cara yang digunakan untuk mencegah dan mengobati suatu penyakit baik secara alami maupun kimiawi. Berbagai tanaman di Indonesia memiliki manfaat dalam mengobati berbagai penyakit mulai dari akar, batang, daun, kelopak bunga hingga biji dari tanaman. Bagian-bagian dari tanaman tersebut dapat dimanfaatkan sebagai obat tradisional. ${ }^{1}$

Pembuatan obat tradisional baru memerlukan karakterisasi bahan baku dan identifikasi senyawa aktif agar terjamin keamanan serta khasiat suatu produk. ${ }^{15}$ Terdapat beberapa faktor untuk menjamin mutu suatu obat tradisional agar tetap memiliki kualitas tinggi diantaranya karakterisasi, standardisasi simplisia dan ekstrak, identifikasi senyawa aktif tanaman hingga menghasilkan isolat murni yang siap dijadikan sebuah produk obat baru. ${ }^{9}$

\section{Rosella (Hibiscus sabdariffa L.)} merupakan tanaman yang sangat mudah dijumpai di Indonesia karena termasuk dalam golongan tanaman rumahan. Kandungan senyawa aktif rosella berfungsi sebagai antioksidan yang baik dan dapat meredam radikal bebas. ${ }^{10}$ Terdapat beberapa golongan senyawa aktif dalam rosella diantaranya asam organik, antosianin yang tercermin dalam warna kelopak rosella, serta flavonoid. Antosianin merupakan golongan flavonoid 
dengan derivatnya adalah gossypetin-8glucoside serta gossypetin-7-glucoside yang menghasilkan pigmen warna alami pada rosella. ${ }^{6}$

Penelitian terdahulu yang berkaitan dengan manfaat senyawa aktif rosella sebagai terapi suatu penyakit yaitu pada ekstrak air kelopak rosella dengan dosis $1 \mathrm{mg} / \mathrm{kg}$ BB hingga $1000 \mathrm{mg} / \mathrm{kg}$ BB memiliki efek menurunkan tekanan darah pada hewan uji dan tidak menimbulkan efek toksik. ${ }^{7}$ Penelitian lain yang dilakukan oleh Barhe et al., (2016) menyatakan bahwa golongan senyawa flavonoid banyak terdapat pada kelopak bunga dengan pigmen warna menarik memiliki manfaat sebagai antioksidan untuk mengobati berbagai penyakit. Flavonoid dapat berperan dalam menangkap radikal bebas sehingga tidak terjadi stres oksidatif dan dapat mencegah penyakit-penyakit degenerativ seperti hipertensi, diabetes, jantung koroner, kanker. ${ }^{8}$ Penelitian ini diharapkan dapat memberikan informasi ilmiah tentang karakterisasi dari ekstrak terpurifikasi kelopak rosella serta aktivitasnya secara oral terhadap tikus Sprague Dawley dalam menurunkan tekanan darah. Pelarut yang digunakan dalam ekstraksi adalah etanol dikarenakan memiliki kepolaran sama dengan senyawa aktif rosella. Ekstrak terpurifikasi dibuat agar lebih meningkatkan peran senyawa aktif rosella yang bebas dari zat pengganggu. Karakterisasi parameter spesifik dan non spesifik ekstrak dilakukan untuk menjamin kualitas kandungan senyawa bioaktif serta uji aktivitas antihipertensi dilakukan untuk melihat bahwa senyawa aktif dalam ekstrak terpurifikasi kelopak rosella dapat menurunkan tekanan darah secara in vivo.

\section{METODE PENELITIAN}

\section{Alat dan Bahan}

Simplisia kelopak rosella yang diperoleh dari kota Kediri Jawa Timur, etanol $70 \%$ (teknis), N-heksan (teknis), akuades, kloroform (teknis), n-butanol (p.a), asam asetat (pa), aquadest. Corong Buchner, Alat Penggilingan, Erlenmeyer, Sonde (5 MILILITER OneMed), Spuit injeksi ukuran 5 MILILITER (Terumo), perangkat alat bedah hewan uji, perangkat KLT (chamber dan fase diam silica gel 60F 254), lampu UV 254 nm dan $366 \mathrm{~nm}$, perangkat alat uji antihipertensi Non Invasive Blood System dari CODA®.

\section{Prosedur kerja}

\section{Prosedur Pembuatan Sampel Ekstrak Terpurifikasi}

Serbuk simplisia kelopak bunga rosella diekstraksi dengan metode maserasi menggunakan pelarut $70 \%$ sebanyak tiga kali pada suhu kamar. Maserat diuapkan dengan vacum rotary evaporator suhunya $60^{\circ} \mathrm{C}$ kemudian diuapkan di atas waterbath suhu $50^{\circ} \mathrm{C}$ hingga didapatkan ekstrak kental. ${ }^{2}$ Proses purifikasi diperoleh dengan metode cair-cair yaitu menimbang ekstrak kental $20 \mathrm{~g}$ dimasukkan dalam corong pisah kemudian dilarutkan kembali dengan etanol $70 \%$. Penambahan penyari dan pengadukan dilakukan secara bertahap hingga diperoleh fase bening. Filtrat yang diperoleh tetap pada corong pisah dan ditambah kloroform $100 \mathrm{~mL}$. Kemudian digojog kurang lebih satu menit dan didiamkan selama 48 jam. Diperoleh fraksi kloroform dan kemudian difraksi kembali dengan kloroform sebanyak tiga kali pengulangan hingga diperoleh fraksi bening. Kemudian hasil dari fraksi dipekatkan hingga diperoleh ekstrak kental dan dihitung rendemen. 


\section{Karakterisasi Parameter Spesifik} Identifikasi Senyawa Kimia dengan KLT

Deteksi kandungan flavonoid dalam sampel menggunakan Kromatografi Lapis Tipis (KLT) dengan fase diam silika gel 60F 254 dan fase gerak menggunakan $\mathrm{n}$-butanol : asam asetat : air (6:6:1). Ekstrak kental dan quersetin ditotolkan pada silika gel 60F 254. Pengamatan dilakukan pada sinar tampak UV-Vis $254 \mathrm{~nm}$ dan $366 \mathrm{~nm}$. Tujuan dilakukan identifikasi flavonoid menggunakan KLT adalah untuk mengetahui profil kromatografi senyawa flavonoid dalam ekstrak terpurifikasi dan menentukan baku standar dengan membandingkan bercak antara ekstrak dan pembanding. ${ }^{12}$ Penampak bercak yang digunakan untuk melihat hasil profil kromatografi, dengan cara diuapi amonia.

\section{Karakterisasi Parameter Non Spesifik}

Penetapan Kadar Air: Penetapan kadar air dilakukan dengan menggunakan metode gravimetri yaitu menghitung hasil penyusutan ekstrak hingga tercapai bobot tetap. ${ }^{3}$ Ekstrak terpurifikasi dikeringkan pada suhu $105^{\circ} \mathrm{C}$ selama 5 jam sampai tercapai berat konstan.

Penetapan Susut Pengeringan: Pengujian untuk susut pengeringan dengan cara memanaskan pada suhu $105^{\circ} \mathrm{C}$ selama 30 menit untuk 1-2 gram ekstrak terpurifikasi kelopak rosella dalam botol timbang. Dimasukkan ke dalam desikator selama 15 menit kemudian dimasukkan ke dalam oven pada suhu $105^{\circ} \mathrm{C}$ sampai kering diulangi hingga konstan. ${ }^{3}$

Pengujian Bobot Jenis: Ekstrak dilakukan pengukuran bobot jenis dengan menggunakan piknometer bersih, kering, dan sudah dikaliberasi, dengan menetapkan bobot piknometer dan bobot air yang baru didihkan pada suhu $25^{\circ} \mathrm{C}$. Atur hingga suhu ekstrak $20^{\circ} \mathrm{C}$, masukkan dalam piknometer. Atur suhu piknometer yang terisi pada suhu $25^{\circ} \mathrm{C}$, buang kelebihan ekstrak dan timbang. Kurangkan bobot piknometer kosong terhadap piknometer terisi. Bobot jenis ekstrak adalah hasil yang diperoleh dengan membagi bobot ekstrak dengan bobot air, dalam piknometer pada suhu $25^{\circ} \mathrm{C}^{3}$

Identifikasi Senyawa Quersetin secara KLT Densitometri: Sebanyak $10 \mathrm{mg}$ sampel ETKR dilarutkan dalam $50 \mathrm{~mL}$ etanol dengan pembanding quersetin menggunakan kadar yang sama $10 \mathrm{mg}$ dalam $50 \mathrm{~mL}$ etanol. Fase gerak yang digunakan adalah toluene:etil asetat (93:7)..$^{13}$ Deteksi secara kuantitatif dengan metode KLT densitometer terhadap ETKR dengan pembanding asam galat. Untuk mendapatkan konsentrasi yang linier terhadap konsentrasi baku asam galat maka ditetapkan kurva baku dan ditetapkan kadar asam galat dalam ETKR.

Uji Aktivitas dalam Menurunkan Tekanan Darah dari Ekstrak Terpurifikasi Kelopak Rosella (Hibiscus sabdariffa L.) terhadap Tikus Sprague Dawley

Hewan uji yang digunakan dalam penelitian ini adalah tikus Sprague Dawley jantan. Hewan uji diperoleh dari lokasi peternakan PAU Pusat Pengembangan Pangan dan Gizi Universitas Gajah Mada Yogyakarta. Penelitian ini sudah mendapatkan persetujuan dari komite etik Institut IImu Kesehatan Bhakti Wiyata Kediri dengan nomor 109/PP2M-KE/IV/2018. Hewan uji dikondisikan pada suhu ruang $22^{\circ} \mathrm{C}\left( \pm 3^{\circ} \mathrm{C}\right)$, dengan keadaan ruang terang selama 12 jam dan gelap selama 12 jam. Tikus diberikan makan secukupnya dan air minum ad libitum (tanpa batas) dengan adaptasi selama satu minggu. 
Hewan uji dibagi menjadi lima kelompok, masing-masing kelompok terdiri dari lima ekor tikus secara acak. Lima kelompok dalam penelitian ini terdiri dari kelompok normal (I) yang hanya diberikan air, kelompok kontrol negatif (II) diberikan suspensi CMC-Na 0,5\%, kelompok kontrol positif (III) diberikan kaptopril, kelompok perlakuan (IV) diberikan ekstrak terpurifikasi kelopak rosella $12,5 \mathrm{mg} / \mathrm{kg}$ BB, kelompok perlakuan (V) diberikan ekstrak terpurifikasi kelopak rosella $25 \mathrm{mg} / \mathrm{kg}$ BB semua diberikan secara oral dengan cara dipuasakan 18 jam sebelum dipejani ekstrak terpurifikasi. Metode yang digunakan untuk penelitian ini adalah kurativ, yaitu memberikan perlakuan ke hewan uji terlebih dahulu untuk menaikkan tekanan darah kemudian diberikan ETKR agar dapat menurunkan tekanan darah kembali. Hewan uji diinduksi Fenilefrin sebanyak satu kali dengan dosis $0,9 \mathrm{mg} / \mathrm{kg}$ BB tikus secara sub kutan. Injeksi fenilefrin dicampurkan pada larutan infus $0,06 \mathrm{mg} / \mathrm{ml}$ dan diberikan jeda 5 menit sebelum perlakuan untuk menaikkan tekanan darah. Sampel ETKR diberikan setiap hari selama 28 hari dan dilakukan pengamatan setiap hari untuk mengetahui adanya perubahan atau tidak pada tekanan darah sistol. Kriteria pengamatan untuk uji hipertensi adalah penurunan tekanan darah yang diukur menggunakan metode Non Invasive Blood Pressure menggunakan Non Invasive Blood System dari CODA®.

\section{Teknik dan Analisis Data}

Penelitian ini menggunakan teknik random sampling, analisa data secara deskriptif untuk prosedur penapisan fitokimia, parameter karakterisasi dan data deteksi KLT, analisa dengan regresi liner untuk kadar total senyawa fenolik dan pengujian anova satu arah untuk aktivitas antihipertensi.
HASIL DAN PEMBAHASAN

\section{Hasil Pembuatan Sampel Ekstrak Terpurifikasi}

Serbuk simplisia kelopak rosella sebanyak 200,12 g diperoleh ekstrak kental sebanyak 75,24 g dan rendemen sebesar $29,75 \%$. Ekstrak kental hasil purifikasi diperoleh sebanyak 25,00 g. Faktor tempat tumbuh tanaman, perbedaan suhu ataupun iklim dapat menyebabkan pengaruh perbedaan hasil rendemen ekstrak. ${ }^{13}$ Rendemen merupakan faktor penting dalam karakterisasi suatu tanaman karena bermanfaat untuk mengetahui kualitas dari ekstrak untuk bahan baku obat tradisional baru. Selain rendemen terdapat faktor lain yang mempengaruhi kualitas dari ekstrak atau simplisia diantaranya sifat zat aktif tanaman atau senyawa metabolit sekunder tanaman dan jenis kepolaran dari pelarut. ${ }^{11}$

\section{Karakterisasi Parameter Spesifik}

\section{Identifikasi Senyawa Kimia dengan KLT}

Hasil deteksi kandungan flavonoid ekstrak terpurifikasi terhadap kuersetin secara KLT terlihat pada Gambar 1.

Hasil deteksi kandungan flavonoid secara KLT menunjukkan bahwa ekstrak terpurifikasi kelopak rosella mengandung senyawa flavonoid sesuai dengan $R_{f}$ pembanding kuersetin yang digunakan.

Deteksi kandungan senyawa kimia bertujuan untuk mengetahui kandungan senyawa kuersetin dalam Ekstrak Terpurifikasi Kelopak Rosella. Baku quersetin memiliki $\mathrm{R}_{\mathrm{f}}$ 0,20 yang sama dengan sampel, atau antara baku dengan sampel sejajar untuk bercak pada plat KLT. Sehingga diduga bahwa ekstrak terpurifikasi kelopak rosella mengandung senyawa kuersetin yang merupakan bagian dari senyawa flavonoid. Senyawa kuersetin 
memiliki peran sebagai antioksidan yang dapat

menekan pelepasan radikal bebas reaktif

sehingga tidak terjadi kerusakan endotel

dengan cara menghambat reaksi rantai

oksidasi penyebab inflamasi organ. ${ }^{14}$

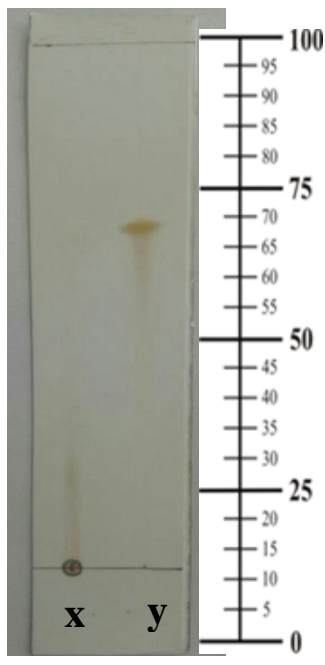

a

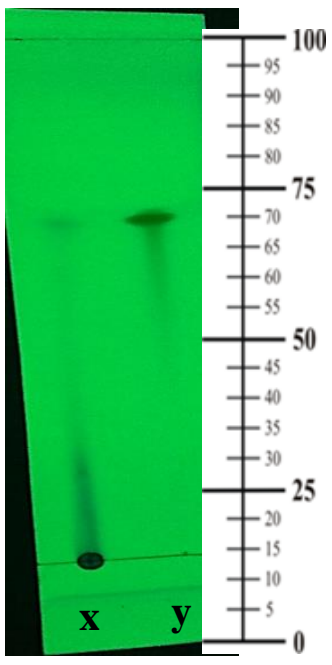

b

Terjadinya inflamasi dapat mengakibatkan aliran darah yang besar menuju aorta atau sebaliknya. Sehingga mengakibatkan tekanan darah meningkat dan disebut sebagai hipertensi.

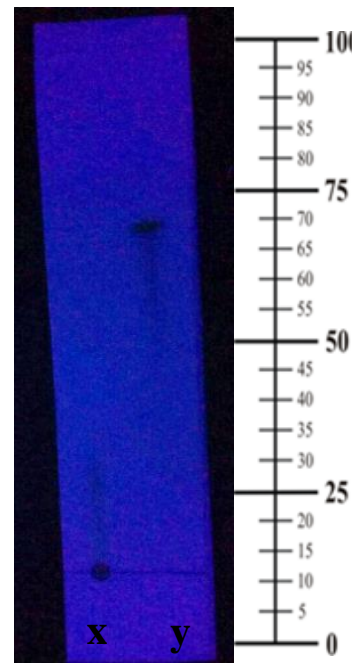

c

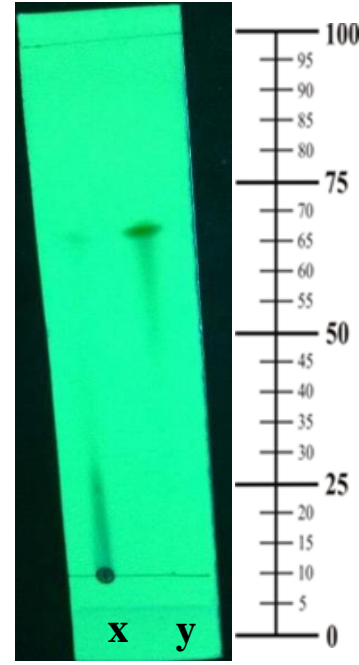

d

Gambar 1. Hasil KLT Ekstrak Terpurifikasi Kelopak Rosella dengan fase gerak Toluen:Asam Asetat:Asam Formiat (6:6:1). (a) Hasil KLT secara visual; (b) Hasil KLT yang dilihat pada UV 254; (c) Hasil KLT yang dilihat pada UV 366; (d) Hasil KLT setelah diuapi dengan amonia dan dilihat pada UV 254; (x) Totolan sampel ekstrak terpurifikasi kelopak rosella; (y) Totolan baku quersetin.

\section{Karakterisasi Parameter Non Spesifik}

Penetapan Kadar Air: Hasil penetapan kadar air menggunakan metode gravimetri diperoleh kadar air sebesar $1,41 \%$.

Penetapan Susut Pengeringan: Hasil penetapan susut pengeringan dengan dari botol timbang satu diperoleh $2,82 \%$ dan botol timbang dua sebesar 2,31\%.

Pengujian Bobot Jenis: Hasil penetapan bobot jenis menggunakan piknometer diperoleh bobot jenis ekstrak 0,63\%b/v.

Karakterisasi merupakan proses uji tentang sifat-sifat tanaman baik dari simplisia ataupun ekstrak. Terdapat beberapa jenis parameter dalam karakterisasi, yaitu parameter spesifik dan non spesifik. Parameter spesifik meliputi uji organoleptis dan uji sifat kimia dari tanaman, sedangkan parameter non spesifik lebih mengarah pada sifat kimia dan fisika dari tanaman yang bertujuan untuk menjamin kualitas bahan baku ekstrak. Pengujian parameter non spesifik Ektrak Terpurifikasi Kelopak Rosella telah memenuhi persyaratan yang tercantum dalam monografi Farmakope Herbal Indonesia untuk parameter non spesifik berdasarkan karakterisasinya. Hal ini menunjukkan bahwa ETKR dalam penelitian ini memenuhi standar mutu bahan baku yang diharapkan dapat menjamin produk yang terstandar pula.

\section{Identifikasi Senyawa Quersetin secara KLT Densitometri}

Hasil linearitas konsentrasi dalam kurva baku sampel ETKR dapat dilihat dalam Gambar 2. Melalui analisis KLT densitometer pengujian kadar total senyawa kuersetin 
Karakterisasi Ekstrak Terpurifikasi Kelopak Rosella (Hibiscsus sabdariffa L.) dan Aktivitasnya Sebagai Antihipertensi Pada Tikus Sprague Dawley

memiliki kadar sebesar 7,02\% $\pm 0,15$ dalam

ETKR tersebut. Hal ini mendukung dugaan bahwa memang senyawa kuersetin yang bertanggung jawab sebagai antihipertensi. Hasil penetapan kadar senyawa kuersetin ditunjukkan dalam tabel 1.

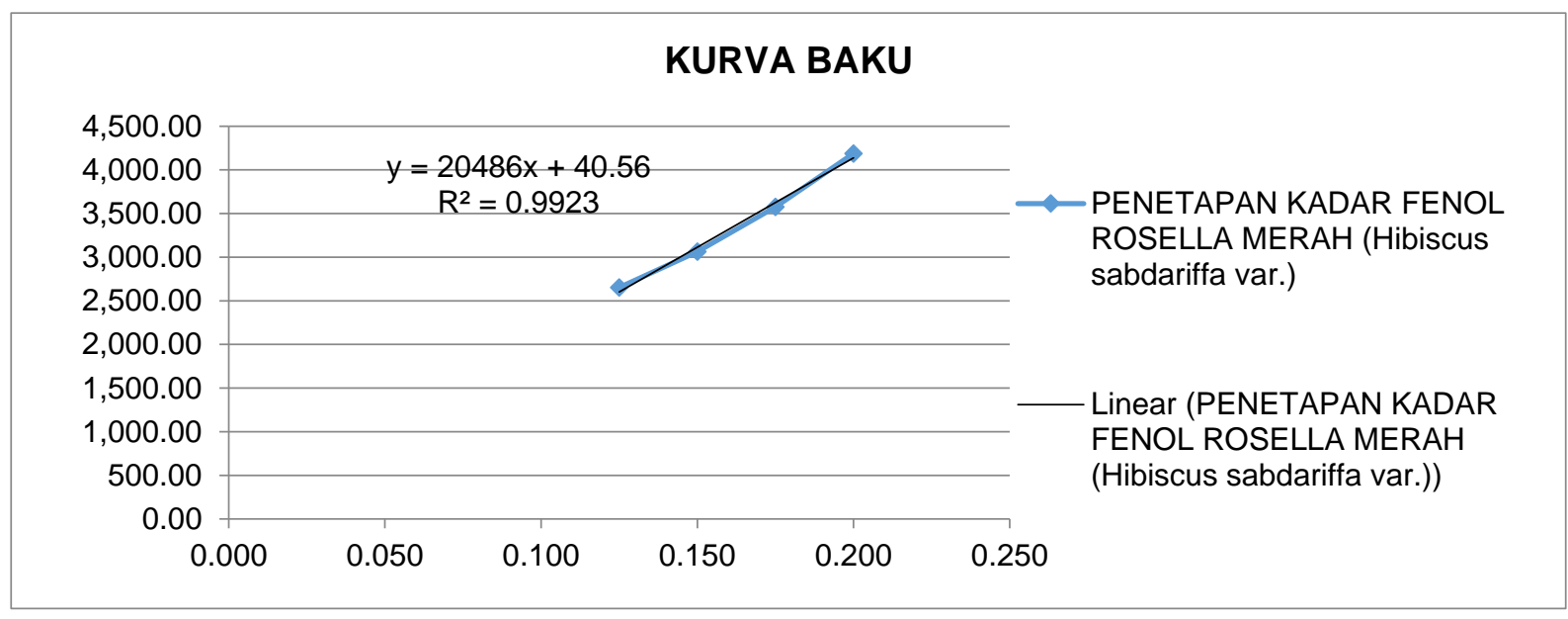

Gambar 2. Kurva Baku kuersetin

Tabel 1. Kadar Senyawa Kuersetin

\begin{tabular}{cccccc}
\hline $\begin{array}{c}\text { Penimbangan } \\
(\mathbf{m g})\end{array}$ & $\begin{array}{c}\text { Volume Penotolan } \\
(\boldsymbol{\mu L})\end{array}$ & $\begin{array}{c}\text { Luas Area } \\
(\mathrm{AUC})\end{array}$ & $\begin{array}{c}\text { Kadar } \\
(\%)\end{array}$ & $\begin{array}{c}\text { Rata-rata } \\
(\%)\end{array}$ & SD \\
\hline 10.00 & 8.00 & 1469.20 & 6.97 & 7.02 & 0.15 \\
10.00 & 8.00 & 1512.80 & 7.19 & & \\
10.00 & 8.00 & 1453.40 & 6.90 & & \\
\hline
\end{tabular}

Uji Aktivitas dalam Menurunkan Tekanan Darah dari Ekstrak Terpurifikasi Kelopak Rosella (Hibiscus sabdariffa L.) terhadap Tikus Sprague Dawley

Ekstrak terpurifikasi kelopak rosella pada penelitian ini dapat menurunkan tekanan darah tikus Sprague Dawley. Data hasil pengukuran rata - rata dan standar deviasi tekanan darah pada tikus dapat dilihat Tabel 2.

Hasil analisis data dengan ANOVA menunjukkan bahwa tekanan darah pada kelompok kontrol negatif berbeda bermakna dengan kelompok normal, kelompok kontrol positif, kelompok dosis tunggal ETKR 12,5 $\mathrm{mg} / \mathrm{kg}$ BB dan $25 \mathrm{mg} / \mathrm{kg}$ BB (nilai sig <0.05). Kontrol positif dibandingkan dengan kelompok dosis tunggal ETKR $12,5 \mathrm{mg} / \mathrm{kg}$ BB dan 25 $\mathrm{mg} / \mathrm{kg}$ BB tidak menunjukkan adanya perbedaan bermakna (nilai sig $>0.05$ ), hal ini menunjukkan bahwa dosis tunggal ETKR 12,5 $\mathrm{mg} / \mathrm{kg}$ BB sudah bisa memberikan efek menurunkan tekanan darah pada hewan uji, akan tetapi dari ke dua dosis yang paling efektif adalah dosis ETKR $25 \mathrm{mg} / \mathrm{kg}$ BB karena efek penurunan tekanan darahnya lebih besar dibandingkan dosis $12,5 \mathrm{mg} / \mathrm{kg}$ BB. Berdasarkan penelitian terdahulu tentang pengujian antihipertensi secara in vivo ekstrak kering rosella menggunakan dosis 150, 250, 350, dan $500 \mathrm{mg} / \mathrm{kg}$ BB menunjukkan bahwa yang paling efektif adalah dosis $250 \mathrm{mg} / \mathrm{kg} \mathrm{BB}$ 16. Hal ini dapat dihubungkan dengan penelitian saat ini, bahwa ekstrak terpurifikasi kelopak rosella dengan dosis $12,5 \mathrm{mg} / \mathrm{kg}$ BB sudah menimbulkan penurunan tekanan darah tetapi yang lebih efektif adalah dosis $25 \mathrm{mg} / \mathrm{kg} \mathrm{BB}$. 
Karakterisasi Ekstrak Terpurifikasi Kelopak Rosella (Hibiscsus sabdariffa L.) dan Aktivitasnya Sebagai Antihipertensi Pada Tikus Sprague Dawley

Tabel 2. Data hasil tekanan darah pada tikus Sprague Dawley

\begin{tabular}{cccccc}
\hline \multirow{2}{*}{ No } & \multirow{2}{*}{ Kode } & 17-May-18 & 24-May-18 & 31-May-18 & 8-Jun-18 \\
\cline { 3 - 6 } & & Tensi $\mathbf{~ m m ~ H g}$ & Tensi $\mathbf{~ m m ~ H g}$ & Tensi $\mathbf{~ m m ~ H g}$ & Tensi $\mathbf{~ m m ~ H g}$ \\
\hline 1 & $\mathrm{~N}$ & $144,6 \pm 3,5$ & $143,6 \pm 2,7$ & $143 \pm 3,4$ & $143,4 \pm 2,1$ \\
2 & $\mathrm{~K}(-)$ & $139,4 \pm 3,3$ & $199,6 \pm 4,7$ & $203,4 \pm 3,5$ & $209,2 \pm 7,2$ \\
3 & $\mathrm{~K}(+)$ & $138,4 \pm 3,3$ & $197,6 \pm 6,3$ & $176,4 \pm 7,6$ & $149,8 \pm 2,7$ \\
4 & $\mathrm{P} 1$ & $138,4 \pm 1,3$ & $200,4 \pm 1,7$ & $178,8 \pm 6,4$ & $169 \pm 5,3$ \\
5 & $\mathrm{P} 2$ & $137 \pm 4,2$ & $199,2 \pm 3,1$ & $178,4 \pm 3,2$ & $146 \pm 2,9$ \\
\hline
\end{tabular}

Keterangan:

$\mathrm{K}(-)$ : kontrol negatif, diberikan CMC-Na 0,5\%.

$\mathrm{K}(+)$ : kontrol positif, diberikan kaptopril 2,25 mg/kg BB tikus.

P1 : kelompok perlakuan, diberikan dosis tunggal ETKR 12,5 mg/kg BB

P2 : kelompok perlakuan, diberikan dosis tunggal ETKR $25 \mathrm{mg} / \mathrm{kg} \mathrm{BB}$.

Hasil penelitian ini menunjukkan bahwa pemberian ekstrak terpurifikasi rosella terhadap tikus SD yang sebelumnya telah dikondisikan hipertensi tersebut adalah aktif dan efektif. Ekstrak terpurifikasi kelopak rosella diduga mengandung golongan senyawa flavonoid quersetin yang memiliki peran sebagai antihipertensi karena dapat menghambat terjadinya inflamasi mengarah pada vasodilatasi penyebab meningkatnya tekanan darah. Penelitian tentang aktivitas antihipertensi menggunakan ekstrak air kelopak rosella pada dosis 250 dan $500 \mathrm{mg} / \mathrm{kg}$ BB tikus hipertensi yang diinduksi garam selama 28 hari menggunakan metode non invasiv menunjukkan penurunan tekanan darah, tetapi tidak berbeda signifikan antara kelompok uji dengan kontrol positif pada tekanan darah diastolik dan sistolik tikus. ${ }^{1}$

\section{Hasil Analisa Data ANOVA}

Hasil analisis data dengan ANOVA menunjukkan bahwa tekanan darah pada kelompok kontrol normal berbeda bermakna dengan kelompok negatif. Kelompok kontrol positif berbeda bermakna dengan kelompok kontrol negatif. Kelompok dosis tunggal ETKR $12,5 \mathrm{mg} / \mathrm{kg}$ BB dan $25 \mathrm{mg} / \mathrm{kg}$ BB (nilai sig $<0.05$ ). Kontrol positif dibandingkan dengan kelompok dosis tunggal ETKR $12,5 \mathrm{mg} / \mathrm{kg}$ BB dan $25 \mathrm{mg} / \mathrm{kg}$ BB tidak menunjukkan adanya perbedaan bermakna (nilai sig $>0.05$ ), hal ini menunjukkan bahwa dosis tunggal ETKR 12,5 $\mathrm{mg} / \mathrm{kg}$ BB sudah bisa memberikan efek menurunkan tekanan darah pada hewan uji, akan tetapi dari ke dua dosis yang paling efektif adalah dosis ETKR $25 \mathrm{mg} / \mathrm{kg}$ BB karena efek penurunan tekanan darahnya lebih signifikan. Kelompok dosis ETKR $25 \mathrm{mg} / \mathrm{kg}$ BB lebih signifikan menurunkan tekanan darah dari awal pemberian hingga hari ke 21 dibandingkan kelompok dosis $12,5 \mathrm{mg} / \mathrm{kg}$ BB dan lebih efektif penurunannya dibandingkan kelompok kontrol positif.

\section{KESIMPULAN}

Karakterisasi spesifik dan non spesifik ekstrak terpurifikasi rosella memenuhi syarat yang tercantum dalam monografi Ekstrak pada Farmakope Herbal Indonesia dan pada dosis ETKR $25 \mathrm{mg} / \mathrm{kg}$ BB lebih efektif menurunkan tekanan darah dibandingkan kelompok kontrol positif pada hewan uji serta diduga senyawa kuersetin (golongan flavonoid) yang memiliki aktivitas sebagai antihipertensi secara in vivo.

\section{UCAPAN TERIMAKASIH}

Peneliti mengucapkan terimakasih kepada Kemenristekdikti atas Hibah Penelitian yang diberikan pada Program Penelitian Dosen Pemula (PDP) 2018. 


\section{DAFTAR PUSTAKA}

1. Abubakar MG, Ukwuani AN, Mande UU. Antihypertensive Activity of Hibiscus sabdariffa Aqueous Calyx Extract in Albino Rats. Sky Journal of Biochemistry Research. 2015;4(3):016-020.

2. Adeyemi DO, Ukwenya VO, Obuotor EM, Adewole SO. Anti-Hepatotoxic Activities of Hibiscus Sabdariffa L., In Animal Model of Streptozotocin Diabetes-Induced Liver Damage. BMC Complement Altern Med. 2014;14(277):1-11.

3. Astuti Indah S, Tulandi Maximus S, Ulfa Maria D. Serial Buku Ajar Analis Farmasi dan Makanan, Analisa Obat Tradisional. Jakarta: Politeknik Kesehatan Kemenkes Jakarta II, 2011.

4. Barhe AT, Tchouya Feuya RG. Comparative Study of The Antioxidant Activity of The Total polyphenols extracted from Hibiscus sabdariffa L., Glycine max L. Merr., yellow tea and red wine through reaction with DPPH free radicals. Arabian Journal of Chemistry.2016;9:1-8.

5. BPOM RI. Standarisasi Ekstrak Tumbuhan Obat Indonesia, Salah Satu Tahapan Penting Dalam Pengembangan Obat Asli Indonesia. Info POM. 2005.

6. Da-Costa-Rocha I, Bonnlaender B, Sievers $\mathrm{H}$, Pischel I, Heinrich M. Hibiscus sabdariffa L. A Phytochemical and Pharmacological Review. Food Chem. 2014; 165: 424-443.

7. Hopkins AL, Lamm MG, Funk J, Ritenbaugh C. Hibiscus sabdariffa L. in The Treatment of Hypertension and Hyperlipidemia: a Comprehensive Review of Animal and Human Studies. Fitoterapia. 2013; 85: 84-94.

8. Kusumawati RI. Roselle (Hibiscus sabdariffa Linn) Effecs on Lowering Blood Pressure as a Treatment for Hypertention. Jurnal Majority. 2014; 3(7): 70-74.
9. Morales G, Paredes A, Olivares A, Bravo J. Acute Oral Toxicity and Anti-Inflammatory Activity of Hydroalcoholic Extract from Lampaya medicinalis Phil in Rats. Biol Res. 2014; 47(1): 6 .

10. Ojedaa $D$, Jiménez-Ferrer $E$, Zamilpa $A$, Herrera-Arellano A, Tortoriello J, Alvarez L. Inhibition of Angiotensin Convertin Enzyme (ACE) Activity by the Anthocyanins Delphinidin- and Cyanidin-3-OSambubiosides from Hibiscus sabdariffa. Journal of Ethnopharmacology. 2010; 127(1): 7-10.

11. Rezki RS, Anggoro D, Mz S. Ekstraksi Multi Tahap Kurkumin Dari Kunyit (Curcuma domestica Valet) Menggunakan Pelarut Etanol. Semarang: Jurnal Teknik Kimia Usu, Article in Press., 2015.

12. Sari RP. Pengaruh Jenis Solvent Terhadap Stabilitas Zat Warna Pada Ekstrak Kelopak Bunga Rosella Dengan Metode Analisa Spektrofotometer (Tesis). Semarang: Universitas Diponegoro, 2015.

13. Sari F, Nurkhasanah, Bachri SM. Uji Toksisitas Akut Ekstrak Etanol Kelopak Rosella (Hibiscus Sabdariffa L.) Pada Tikus Sprague Dawley. Trad. Medicine Journal. Universitas Gajah Mada. 2016; 21(1): 1218.

14. Siregar RNI. The Effect of Eugenia Polyantha Extract on LDL Cholesterol. J. Major. 2015; 4(5): 85-90.

15. Pramono S, Ajiastuti D. Standardisasi Ekstrak Herba Pegagan (Centella asiatica (L) Urban) Berdasarkan Kadar Asiaticosida secara KLT-Densitometri. Majalah Farmasi Indonesia. 2004; 15 (3): 119-123.

16. Susilawati $Y$, Rahmatullah ST, Muhtadi A, Sofyan FF, Tjitraresmi A. Aktivitas Antihipertensi Ekstrak Kering Terstandardisasi Kelopak Bunga Rosella (Hibiscus sabdariffa L.) Hasil Produksi Skala Pilot. Jurnal Sains dan Kesehatan. 2018; 1(10): 554-560. 